CIRR XXIII (79) 2017, 127-156

ISSN 1848-5782

UDC 327.5(829.7:4 1-4)

DOI 10.1515/cirr-2017-0017

\title{
Preserving 'Great Power Status': The Complex Case of the British Intervention in the Falklands (1982)
}

Matthieu Grandpierron

\section{Abstract}

This article aims to examine the importance of an often overlooked argument when it comes to explaining why great powers go to war against a weaker actor. This argument involves great power status considerations. The article argues that states care deeply about their status, especially states which are current and former great powers, and would opt to go to war to preserve this status even if the political and military consequences of such intervention are negligible to objective observers. To illustrate this argument, I will be looking at why the British decided to reestablish their sovereignty over the Falklands in 1982. The empirical part of the analysis is based on formerly secret documents declassified by the British government. This qualitative primary analysis of British documents provides new insights about the crisis and suggests that status considerations played a large role in the British decision to re-conquer the Falklands.

\section{KEY WORDS:}

great powers, status, recognition, status perception, United Kingdom, Falkland Islands 


\section{Introduction}

In 2010, the British government began declassifying documents related to the Falklands crisis (1982). These documents are now available on the Margaret Thatcher Foundation website. They are related to the negotiations with Argentina and cover the crucial period 1979-1982, when the situation spiraled out of control and ended up in a military conflict. These documents are largely comprised of reports from the cabinet's internal discussions as well as communications from the Falklands' governor. They offer a great deal of information on how the British government perceived the Falklands issue; they also provide information on how the island's residents perceived their situation and also the pivotal role of Argentinean public opinion.

It is important to analyze these newly declassified documents to confirm the relevance of previously applied theories to explain why negotiations failed and war ensued 32 years after the fact. The Falklands crisis also had other consequences that still stand today: the islands' sovereignty continues to be an important issue for Argentina and the United Kingdom to such an extent that the UK organized a referendum in 2012 to ask the islanders if they wanted to remain British. The result was $99.8 \%$ in favor of a British citizenship (Falkland Islands Government 2013). As soon as the results were revealed, Buenos Aires qualified it as illegal and argued that the islands belong to Argentina. London has permanently deployed fighter squadrons to ensure air superiority in that region and to - de facto - deter Argentina from invading the islands again. The aim of this article is not to explain the conflict itself, but rather to provide an explanatory model as to why Britain decided to risk its entire navy and international prestige to re-conquer remote islands in the South Atlantic.

\section{Literature review}

Many books and articles are dedicated to the Falklands crisis. This abundant literature can be divided into three major categories. (1) The 
first is made up of works from decision-makers involved in the conflict (Thatcher 1993; Haig 1984; Weinberger 1990; Costa Méndez 1993; Menéndez 1983) and from officers and soldiers who were deployed on the battlefield (Woodward 1992; Thompson 1992; Piaggi 1998; Bramley 1993; Lawrence and Lawrence 1988).

(2) The second category in the literature is composed of historical works. A part of this cohort describes and presents the conduct of the war and of military operations (Adkin 1995; Gordon 1989; Middlebrook 1985 and 1989; Schmitt and Green 1985; Calvert 1982; Hastings and Jenkins 1983). Another part focuses on describing the value proposition bargain from a factual point of view and how the crisis was (mis) managed by the two sides, but with very little convincing theoretical evidence developed (Freedman 1982 and 1988; Williams 1983). Douglas Kinney also takes this perspective but offers an explanation as to why the two sides couldn't find any peaceful resolution to the dispute prior to the conflict. His argument is that no agreement was reached due to the view of the world the two countries had and their lack of imagination in finding a mutually facesaving compromise. In addition, there are studies about the legal aspects of the conflict in relation to international law (Calvert 1983; Windsor 1983; Schmitt and Green 1985; Franck 1983; Bluth 1987; Perl and Larson 1983).

(3) The third category is composed of academic works. Most of them concentrate on explaining the Argentine decision to invade the Falklands (Welch 1997 and 2005). The most common argument is the diversionary theory of war: Jack Levy and Lily Vakili (1992) highlight the impact and decisive importance that the Argentine domestic and social situation had on the Junta and on its desire to recover the island to salvage its political leadership.' Other scholars defend the idea of mutual misperceptions (Paul 1994; Rotberg and Rubb 1984). However, there are very few studies that explain the Falklands conflict from the British side. One of the most notable works is that of Virginia Gamba (1987) but unfortunately, her work presents more the general international and political context in which Britain was from 1945 to 1982 and not the actual British motivation to go to war. The most widely accepted theoretical argument is that Thatcher took the decision to re-conquer the Falklands in order to save her political

To go to war to distract domestic opinion from domestic shifts in order to gain public support and ultimately win the next elections (Sobek 2007). 
career and shift the focus away from her domestic policies. With only access to the conflict timelines and studies of the British domestic context, the argument of diversionary war appears to be relevant and tempting to accept. However, a detailed study of declassified documents proves that both Thatcher and her government were not particularly concerned by the outcome of the next elections when they took the decision to send the entire Royal Navy on 5 April.

Other IR scholars, particularly Richard Ned Lebow (1983) and David McCourt (2014) have argued that Britain reacted this way to the Argentine invasion because of prestige factors (Lebow) and national identity considerations (McCourt). These arguments seem closer to reality, but they suffer still from some limitations. Lebow's work is flawed from evidence limitations as recognized by the author himself: "in the absence of these documents the investigator can only piece together the outlines of the story from evidence available at this time [speeches, interviews, newspapers account]" (Lebow 1983). The available documents in 1983 are problematic to use because when it comes to speeches, interviews and newspapers reports, we cannot be certain if what is said and written is accurate and reflects real motivations or is an expression of the way politicians want the audience to understand a given situation. The other concern is that it explains the conflict from a crisis management point of view and emphasizes miscalculations, but barely provides theoretical explanations as to the reason why miscalculations occurred. However, his claim that prestige and status considerations played an important role in the British decision to go to war is a solid conclusion as this study will show. McCourt's work takes several key events involving Britain (the Suez crisis, the Skybolt affair, the Falklands' crisis) and demonstrates how Britain constructed its role during these events, based on the use of George Herbert Mead's concepts of role-taking, role-playing, and alter-casting. However, his work does not directly examine the British government's motivations to go to war against Argentina. 


\section{Theoretical section}

Why would this research be different from those already existing? Firstly, because I rely primarily on declassified documents to base my claims (see the data collection part for more details), which enable me to have a clear insight into the British decision-making process and mindset at that time. Based on this evidence, I will make the argument that the British motivation to retake the Falklands was essentially based on status and prestige considerations.

\section{Great power status and its implications}

\section{Defining great power and great power status}

The term "great power" was first used in 1815 during the Vienna Congress to name states having the responsibility to create and sustain international rules (Nolan 2006: 72). Since 1815, the terminology of "great power" is often used in IR to name the most important and powerful countries. When it comes to providing criteria to identify great powers, there is a strong tendency use only material criteria, such as economic and military power: "a great power, almost by definition, is one which has the capacity to control events beyond its own borders; and that is usually based on the ability to use military force" (Howard 1971: 254; Rothstein 1968; Levy 1983; Modelski and Morgan 1985; Gochman and Maoz 1984; Baron 2013; Mearsheimer 2014). However, this understanding is too limited: focusing on military power and economic power, although important, is not enough (Duque 2015). To give a more accurate definition of what a great power is, identification criteria should rather be based on the three types of power identified by Robert Dahl (1957), Steven Lukes (1974), and Michael Barnett and Raymond Duvall (2005). These three aspects of power can be found in Manjeet Pardesi's recent works. In his article "Is India a Great power? Understanding Great Power status" (2015), he explains that great powers are countries having security and economic related interests outside of 
the home region, that they have capabilities to promote their interests and that finally they have seen their aspirations to be considered as great powers recognised. Based on this, it seems to be more accurate to define a great power as a state possessing the five following characteristics: (1) having interests (economic, strategic, diplomatic or cultural) in other region(s) than its home region and being able to prevent other actors from following policies harmful to its interests or to compel others to bow to some extend to its interests; (2) then a great power is also a country having both the resolve and capabilities to be active on the international stage (promoting initiatives, imposing norms/rules of conduct, controlling the agenda and taking the lead to find solutions to global issues). A great power is a state having resolve/will/willpower and because of that will not be irresolute about its behaviours and policies. A great power is, therefore, an active state and influential on the international stage, a state that offers solutions to international issues. Although successful outcomes are more desirable, failures, to some extent, are inevitable; what is important is the level of activity deployed by the state; (3) a great power is also a country enjoying freedom of action on the international stage, having a certain level of autonomy to take foreign policy decisions or to resort to the use of military force; (4) Finally, it is a country that has been granted the status of a great power by other international actors, meaning that this country has been recognised to possess the previous criteria. The two essential criteria are number 2 and number 4: willingness to be active on the international stage and to assume special responsibilities, and recognition from other actors.

Status can be defined as "the rank an actor occupies in a given social group" (Onea 2014: 129) and has at its core the notion of social groups' consensus about the position an actor has in a given hierarchy (Dafoe, Rensthen and Huth 2014). "Status often hold 'social roles', such as being dominant within a group, having moral authority within a group, being the leader of a coalition, or being the defender of a group of people" (Dafoe et al. 2014: 374). A given position in a hierarchy has prescribed duties, functions to be performed, and rights to be enjoyed. Great power status is a very particular type of status, because it goes along with expected higher task performances and a better ability to resolve regional and international issues (Forsberg, Heller and Wolf 2014: 263-264). Since the Vienna Congress (1814-1815) great powers have attributed themselves 
with, and the international community has recognised the existence of a specific responsibility: to prevent further war from breaking out, as well as to tackle future international crises (Battistella 2012: 663). Special duties embodied in the status of a great power have changed according to the global context. The first special duty was to maintain the balance of power and to defend states' right to have an independent existence (Nolan 2006: 74). This first task has been gradually extended to the preservation of the actual order: that is to say preventing physical aggression (Morris 2011 ) but also preventing (and punishing) aggression in contravention of international law (Jackson 2000: 202). In exchange for responsibilities at the global stage and status, great powers must prove their commitment to fulfil these expectations, even if it is costly (Bukovansky et al. 2012; Nolan 2006). Great power status provides privileges: states enjoying it cannot be ignored in resolving international issues and when it comes to negotiating agreements, the supposed gap of power between the great power and its counter-parts makes the weaker actor agree to the great power's terms (Aron 1962: 68). More generally, "the group is more reticent to impose, it makes requests more carefully, and it offers various public signs of respect" (O'Neill 2001: 139). Claimed status has to be recognised by others to be fully enjoyed. The recognition process is therefore a two-step process: self-recognition and then recognition by others. In this process I identify three components, called the 'three circles of recognition'.

\section{Attaining and retaining great power status: a Sisyphean task}

\section{The three step process to earning great power status}

When a country consistently fulfils the great powers' criteria elaborated above, its leaders/ruling elites and its citizens start to believe their country is special; and because their country is special, they should be considered differently from other countries. A feeling of superiority, or at least an impression of being different from and unique compared to others enhances national self-esteem. There are two clearly defined groups of 
states: all the others and their country. To ordinary people as well as to ruling elites, it is unthinkable that their country could be anything less than a great power. The great power status recognition starts, therefore, by self-recognition/attribution of this particular status. This step is essential. If leaders/ruling elites are not convinced their country is a great power, how could they ask others to grant them this status? To make use of a comparison from theatre: an actor needs to believe he is the character he will be playing during the theatre play. If the actor is not persuaded he is indeed the character he will be playing, then the audience will notice and refuse to acknowledge that it is anything more than a theatre play. The insistence that their country should be seen as a great power and granted privileges and prestige linked to that position becomes a key element of a state's foreign policy until full international recognition occurs (Forsberg, Heller and Wolf 2014: 262). Self-attribution of status is, of course, necessary in the quest for this status, but it is not sufficient. What is lacking is being recognised by others. The state needs the approval of others to achieve status. They are used by the state as a mirror on which its image is reflected: "social status rests on collective judgment, or rather a consensus of opinion within a group. No one can by himself confer status on another, and if a man's social position were assessed differently by everybody he met, he would have no social status at all" (Marshall 1977: 198 quoted in Paul et al. 2014: 8). Approval of two other circles- evolving states enjoying different status - is required.

The second circle is composed of actors already enjoying the sought after status, that is to say in this case the second circle is composed of other great powers. When a country is believed to perform the role(s) and to satisfy most of the great power criteria, it is recognised by other great powers as a member of their "club". At its beginning, "the great power system was rather like a British gentleman's club, with admission controlled by the existing members. If established great powers begin to treat another state as one of their members, that country ipso facto became a great power" (Scott 2006: 119). The decision to co-opt new members by already recognised great powers is rather a subjective process than an objective one based only on material criteria. Co-optation, indeed, means, more or less, being the same, having the same characteristics as others have. Actors who are already members of a group impose their views, goals and behaviours and potential members have to follow these 
rules in order to become members of the group. Recognition/co-optation by the second circle is important: high status group members (other great powers) are more prominent and influential in their opinion and their help is sought more often; their actions and behaviours draw particular attention and their positions taken and policies carry more weight than those of other actors (de Waal, Gregg and Lammers 2015: 447). This step is a good achievement but is only partial because the group of great powers is a small sample of actors (normally no more than ten countries). Of course, being recognised by great powers as being a pre-condition of great power legitimacy, it still needs a stronger stimulus. It needs support (recognition) from the remaining actors. To achieve full recognition, a country needs to see its status recognised by a bigger group, that is to say the international community.

The international community is the third and last circle. Status recognition from the third circle usually follows the recognition from the second circle, because international actors tend to mirror what great powers do. For example, when great powers decide to open an embassy in a state's capital city or to recognize the existence of a new country, other countries tend to mirror this decision. The third circle exhibits most of the time the behaviour of an audience during a theatre play. During a theatre play, the audience can consider or not the performance as appropriate (well performed) and confirms the reality of the role. The third circle has exactly this function. It watches the second circle acting and gives the status of great power to states performing the way great powers should. That does not mean that countries belonging to the third circle cannot develop autonomous foreign policies. It simply means they do not have much impact on world politics. These countries have barely any capabilities and are therefore out of play (Badie 2013: 84). However, if the third circle is not convinced by the performance, it may stop treating the state as a great power. The way the third circle behaves toward a great power is a sort of reality-testing. The image of great power a state gives is tested, evaluated by the third circle against observations of the great power's behaviour on the international stage. Once status is achieved and recognised, the quest for status does not really end, like Sisyphus constantly trying to roll a boulder up to a hill, only to watch it rolling back down, repeating this action again and again. 
To keep great power status, those who attributed to have it must believe the state continues to meet the required criteria in producing an appropriate status signalling. This demands constant efforts, "the whole group has an inducement to pressure the individual to behave correctly" (O'Neill 2001:91). Great power status has been granted because the state was perceived as being legitimate in having the capabilities required and resolve to take roles associated with great power status. A great power's legitimacy to be a great power is compared not only to other members of the group, but it is also compared to the great power's past. Other great powers' capabilities and behaviour and the state's past are used as reference points in which symbols often play an important role: "statusseeking actions can be largely symbolic and aimed at influencing other's perceptions" (Welch Larson and Schevchenko 2010: 5). When these efforts cannot be afforded for a long time, or if wrong and inappropriate status signalling actions are sent, then it can encourage the second and third circles to stop perceiving a country as being a great power, and in this case great power status and correlated rights are put at stake. Inappropriate or wrong status signalling can take several aspects. Firstly, it can take a material shape (e.g. the reduction of the size of the military or of its budget) for various reasons. Then, inappropriate and wrong status signalling can also take a more informal aspect. In this case, all is based on assumptions and perceptions: for some reasons a great power is alleged to be less efficient and influential in its role(s); as a result, its will of being and acting as a great power is questioned. This second type of inappropriate status signalling tends to be harder to deal with because everything is based on perceptions and interpretations of a given behaviour.

A country suspected to be sending inappropriate status signals can endure status uncertainty. The second and third circle (and sometimes even the country's domestic opinion) start to have doubts about the real capacities of the country to be a true great power. Status uncertainty, if not addressed quickly, tends often to lead to what is called 'the recognition denial' (Lindemann 2010). The recognition denial is the gap between the claimed frame and the frame perceived by others. There is recognition denial when the image a state has of itself is higher than the image given back by others. The more important the gap is, the stronger feelings of 
frustration (and even humiliation) are (Lindemann 2010: 51). Status denial tends to lead to an increase of challenges and what is perceived as provocation by the state facing status uncertainty as the fear factor included in great power status is eroding. In this sense, challenges are a symbolic demand of a proof of great power. To avoid status denial, the state must "demonstrate their possession of qualities that warrant their acceptance" (Lebow 2010: 94). If the challenged great power responds to the challenge(s) in a satisfying manner, the challenges might stop. But if not, then challenges might continue until the imposture is revealed to all. Hence the need to make the second and third circles to see the state as a great power. The shape of actions to take can differ, but it "often requires publicly incurring some cost or risk, often by participating in violence" (O'Neill 2001: 91).

What happens in the case of a challenge from a weaker actor? Being challenged (or worse attacked) by a weaker actor is humiliating because the simple fact to be a great power should deter weaker actors from challenging the state. The fact that an inferior actor challenges a great power is deeply humiliating: it provokes anger when a challenge "comes from an actor who lacks the standing to challenge or insult us [...]. Great powers feel enraged if challenged by such a state" (Lebow 2008: 69). This challenge can create doubts about the reality of the great power status. The expected behaviour from a great power is to put the inferior actor back in its place. If this expected task is not performed (or performed with difficulties), questions will arise about the legitimacy of the state claiming great power status. As noted by Bevan Sewell and Maria Ryan: "once the symbol [of weakness] was created, there was no turning back" (Sewell and Ryan 2017: 293). The challenged great power may be sending inappropriate status signals (cuts in the arm forces, diplomatic difficulties to weigh on the international stage, retreat from world affairs, etc.) In this scenario, the situation can quickly become difficult. The challenged state will have to decide between attempting to punish the challenger to send an appropriate status signal and thus taking the risk to publicly fail because it has no more capabilities to do so. Or, the state can decide not to react to the challenge, making clear that the second and third circles were right to interpret its signals as inappropriate for a great power. The dilemma for states facing status uncertainty is the following: to maintain great power status, the challenger has to be punished severely 
(and decisively), but taking the decision to go to war can lead to a more damaging consequence in the case of a failure: a great power defeated militarily by a weaker actor would be very embarrassing. First, because of the defeat but also because intervening in peripheral regions has important symbolic aspects. A challenge in the periphery may have zero effect on vital interests, but is highly symbolic: "when engaged in a conflict for global stakes, what may appear as a marginal interest will be invested with a significance it would not otherwise have, for almost any challenge is to be seen by the challenger and by third parties as a test of one's will" (Tucker 1981: 144-145 quoted in O'Neill 2001: 105).

\section{Methodology}

\section{Research design}

The research instrument I use to analyse the declassified documents is discourse analysis. Discourse analysis is defined as the "qualitative and interpretative recovery of meaning from the language that actors use to describe and understand social phenomena" (Abdelal et al. 2009: 6). It is in speeches and in written documents that perceptions of a given situation can be found. For example, if it appears that status and prestige considerations are the cause of the decision to go to war, then words or idioms expressing these ideas should be found in documents before the decision to go to war is taken. However, there are two major risks in applying the discourse analysis method to leaders' discourses and writings. The first one is: how can we be sure that what is said or written by leaders is the truth? This risk has been highlighted by Paul Saurette (2007), and many others. Saurette studied the motives George Bush had when he took the decision to invade Iraq in 2003. They were basing their analyses on public discourses Bush made. When studying public discourses, it must be taken into account that these discourses are addressed to domestic public opinion as well as to international public opinion, while books written by politicians are often used as justification a posteriori. I mitigate this risk in the data collection section, where I explain that I have selected mainly 
Declassified documents enable us to avoid the first risk because they give us unique insights from the decision-making processes. As the documents were first designed to remain classified, there is less risk that what is written is untrue. The second risk is lying about "hidden interests". How to affirm that what is assigned to emotions, identities, perceptions is not a useful mask to hide material interests? It is mitigated too by the use of declassified documents. Indeed, they give insights into the decisionmaking process leading to war and therefore, reveal what were thoughts and considerations of decision-makers at the time the decision was taken. Maybe there are material interests but the documents would reveal that these material interests did not matter to them. These documents would also reveal whether decision-makers were conscious or not of the potential existence of material interests.

\section{Data collection}

A series of documents on the Falkland crisis have been declassified since 2010 by the British government and published on the Margaret Thatcher foundation's website. ${ }^{2}$ These documents are very valuable because they consist of transcripts of both the secret and public negotiations between Argentina and Britain, of reports to the British Government from the Falklands Governor, of reports from the British Embassy in Buenos Aires of the Argentine public and of government opinions regarding the issue. The documents also consist of personal notes to Margaret Thatcher from her advisers, and even more valuable, most of these notes are annotated by Thatcher herself, which enables one to have a good idea on how she was perceiving the situation. As a result, these declassified documents give the opportunity to know what happened behind the stage; as politicians do not always show the same considerations in public or in secrecy. In total 1.840 documents related to the Falklands war have been declassified and published by the British government. I actually limited myself to 328 of these documents as this paper is focused on the decision to go to war and not on what happened after the decision to respond was taken and the Navy received the order to sail to the South Atlantic. That is why I studied

2 For each document quoted, the reader will find the access link in the references. 
and analyzed only the documents from 10 May 1979 (the first declassified document was issued at this date) to 7 April 982 (debates at Parliament after the fleet departed). The documents used are classified as follows.

Table 1: classification of the British sources.

\begin{tabular}{|c|c|}
\hline Type of documents & $\begin{array}{l}\text { Number of } \\
\text { documents }\end{array}$ \\
\hline Reports regarding the history of the Falklands' dispute & 8 \\
\hline Propositions for future policy in the Falklands & 4 \\
\hline Comments on future policies by ministers & 6 \\
\hline $\begin{array}{l}\text { Documents related to UK-Argentine negotiations (including direct } \\
\text { messages from UK ministers to Argentine ministers and vice versa }\end{array}$ & 21 \\
\hline Minutes between ministers & 73 \\
\hline $\begin{array}{l}\text { Documents issued by the Foreign and Commonwealth Office (FCO) to } \\
\text { ministers. }\end{array}$ & 23 \\
\hline FCO to UK embassy in Buenos Aires & 23 \\
\hline Minutes and letters to Margaret Thatcher (MT) & 43 \\
\hline Letters from MT to FCO & 13 \\
\hline $\begin{array}{l}\text { Reports on the situation in Argentina (on the economy, military and } \\
\text { political situation, including Argentine press opinion) }\end{array}$ & 17 \\
\hline Reports on discussions during Defense and Overseas Policy Committee & 14 \\
\hline Reports from Ministry of Defense (MOD) to FCO & 6 \\
\hline Public interventions of MT & 6 \\
\hline FCO to Port Stainley & 8 \\
\hline Letters from and to the governor of the Falklands & 9 \\
\hline UK-US talks (excluding Haig's letters) & 10 \\
\hline Reports on British ministers' visits to the Falklands & 2 \\
\hline Reports to the Cabinet on the House of Common's position & 2 \\
\hline Minutes to the Cabinet & 7 \\
\hline Reports from the UK Embassy in Buenos Aires & 31 \\
\hline $\begin{array}{l}\text { MT messages to Head of States and vice-versa (including Ronald } \\
\text { Reagan) }\end{array}$ & 10 \\
\hline
\end{tabular}


The hypothesis derived from the theoretical considerations I made previously is that great powers perceived as being in decline will respond to an aggression in their periphery by the use of the military force in order to maintain their state's status. If this hypothesis is correct, then discussions, speeches or notes evoking the place of the country on the international stage should be found within the declassified documents. The table below gives some examples of words and expressions (in bold) found in the declassified documents and linked to the theory previously explained. ${ }^{3}$

Table 2: examples of expressions supporting my theoretical claims

\begin{tabular}{|l|l|}
\hline Hypothesis & Verification \\
\hline & $\begin{array}{l}\text { - "the significance of the Falklands was enormous [...] for our } \\
\text { standing in the world" }\end{array}$ \\
$\begin{array}{l}\text { Restoring prestige and } \\
\text { great power's identity }\end{array}$ & $\begin{array}{l}\text { - "since the Suez fiasco [...] we had come to be seen [...] as } \\
\text { a nation, which lacked the will and capability to defend its } \\
\text { interests [...] victory in the Falklands change that" } \\
\text { - "a British readiness to surrender sovereignty over the Falklands } \\
\text { might have implications for the British positions [...]" }\end{array}$ \\
\hline
\end{tabular}

\section{Case-study: Britain confronted in the Falklands' crisis}

The analysis of the case-study of the British decision to go to war to reconquer the Falklands Islands aims to highlight the role status considerations and emotions played. This section is organised as follows: in the first part, I will recall elements that show Britain was facing great power status denial; then, in the second part and based on a qualitative analysis of declassified documents, I will highlight that status considerations and the desire to be recognised again as a great power played an important role in the British decision to go to war.

3 Only documents providing the most relevant examples will be directly quoted in this paper. 
The remaining consequences of Suez: is Britain still legitimately claiming great power status?

\section{From Suez to the Falklands: a succession of embarrassing military issues}

The Suez fiasco in 1956 had a disastrous impact on British prestige. It also had an impact on how British citizens were seeing their country in the world and the place they thought Britain had on the international stage. Before Suez, they were persuaded that their country was on the same level as the USA and the USSR: they thought they could compete with these states. After all the United Kingdom was the only European country involved from the beginning until the end of the Second World War and which successfully prevented a Nazi invasion (Marx 1993; Chassaigne 2009). After the end of WWII and despite its economic and industrial weaknesses, British diplomacy managed to create the impression that Britain was the only country which could bridge the differences between the US and the USSR: the UK was the country to which European countries should be close to in order to be connected to the US and the country to which the US should be linked to if they wanted to keep good relations with European states and also with the Soviets. But Suez changed everything; the image that the UK was a great power literally exploded. The British had to withdraw from the Suez Canal because of US and USSR pressures (Moscow even threatened to use nuclear weapons and Washington launched a financial offensive on the British Pound). The Suez failed expeditions revealed two weaknesses Britain had: first, that its conventional forces were not adapted and were using outdated WWII equipment (Robbins 2013). Secondly, without nuclear weapons, the UK was vulnerable to international pressures, especially from US and Soviet pressure.

Since the end of WII, Britain had seen its military capacities decrease. Britain had no nuclear weapons and a solution to change that was to buy nuclear systems from the US (the Polaris missiles for submarines). However, this solution appeared to be extremely costly and had consequences on the defence budget: the choice was either obtaining a deterrence capability or developing new programs (such as new ships for the Royal Navy). The decision to acquire Polaris missiles certainly did provide nuclear systems to 
the UK, at least in theory. There were persistent rumours that Britain was not an autonomous nuclear power because a Washington agreement and double-key procedure were limiting the use of British nuclear weapons: "during the period from mid-1958 to March 1962, the British government would have had to secure US permission and authorization to arm the more reliable half of the V-Bombers" (Bronk 2014: 994). Although these rumours have been denied by the British government, they were revived each time the British had to renew its systems. Conventional forces were not in a much better state. Since the 1960's Britain no longer had any modern aircraft carriers, which is quite problematic already for a great power, but it is even more problematic due to the image of the Royal Navy. ${ }^{4}$ An aircraft carrier is considered to be a visible instrument of a state's power (for example : a US aircraft carrier sailing through the Strait of Taiwan helped de-escalate the tension between Taiwan and China in 1996). Due to the psychological impact linked to the possession of an aircraft carrier and its military power and value, it is not surprising that Henry Kissinger (when he was US Secretary of State) always opened an emergency session with the sentence "where are the carriers?" (Holloway III 2007). The embarrassing combination of military and economic weaknesses, of military and diplomatic humiliations, and of a global British disengagement from world affairs, has made foreign diplomats ask their British counterparts the question "what has happened to your country?" (McCourt 2011: 1618). Last but not least, once the Falklands have been invaded, Britain suffered another humiliation through its military. Indeed, once the small British Garrison surrendered, they were humiliated by the Argentinians by being forced to lay on the ground, face on the ground and pictures were taken of them in this position. These pictures were released. This has been perceived as outrageous by the British, and Thatcher mentioned this surrender in her speech at the House of Commons in which she emphasized that Royal Marines fought well "in the pure tradition" of British forces, and that ultimately, British armed forces will have the opportunity to take revenge on this humiliation (Thatcher 1982a).

4 The Invincible class commissioned in 1980 (HMS Invincible, HMS Ark Royal, HMS Illustrious) weighed 22,000 tones and could carry only 22 STOVL aircraft. There are two types of aircraft carriers. The first one is called CATOBAR (catapulted assisted take-off barrier arrested recovery) and the second one is called STOVL (short take-off and vertical landing). The first type is considered more efficient because the aircrafts are launched by a steam catapult, they can carrier more armament and fuel. Whereas in the second type, aircrafts need to be lighter in order to be able to take off without help, therefore they can carry fewer munitions and fuel, their autonomy is less important. Possessing an aircraft carrier is considered as the ultimate display of a country's prestige and influence as the former head of the Royal Navy Admiral Sir Mark Stanhope said: "to put it simply, countries that aspire to strategic international influence have aircraft carriers" (BBC News 2012). 


\section{Endurance: the UK further in retreat?}

The Falklands issue raised concern about British resolve and commitment, because of the perceived gap between the official positions and the policies taken. Officially, the British position regarding the Falklands was no sovereignty transfer. In 1979 Thatcher annotated a report from Lord Carrington (the Foreign Minister), in which Carrington explained that, the best solution regarding the Falklands would be to proceed to a sovereignty transfer to Argentina. Next to the proposition, Thatcher annotated: "I could not possibly agree" (Carrington 1979). However opposite signals were sent: in the meantime, the defense budget was decreased, the Royal Navy's tasks concentrated on hunting Soviet submarines in the North Atlantic, and HMS Endurance was decommissioned. HMS Endurance is an ice patrol ship, which has zero military value but was he only ship the Royal Navy permanently deployed in the Falklands, withdrawing and decommissioning it gave the impression that Britain was slowly retreating from this region. This decision raised some concerns among British politicians as recalled by Lord Carrington: "I remain concerned at the strength of public and Parliamentary opposition to HMS Endurance's withdrawal and at consequences for our position on the Falklands" (Carrington 1982).

\section{Stopping once for all humiliations and status denial; sending a strong signal to the world: "we are back in control"}

\section{Going to war for the Falklands to send an appropriate signal about} British great power status.

Sending the entire Royal Navy to the Falklands was a very risky decision. Nothing could have predicted nor guaranteed a British success. The islands are 13,000 km from Britain and the nearest supply port and airport Britain could use were at the Ascension islands, $6.000 \mathrm{~km}$ away from the Falklands, putting British strategic bombers out of range. Compared to the British, the Argentinians would operate at "only" $700 \mathrm{~km}$ from their bases. Winning a war in these conditions would certainly restore British prestige in the world. It would first prove that Britain has the capacity to project its hard power far away, but demonstrated it also had the financial capacity 
and resolve to do so: it has to be remembered that the decision to send the Royal Navy had been taken very quickly. The islands were invaded on 2 April and the task force sailed three days later, on 5 April. As the UK was considered to be in decline, a victory in the Falklands would be considered as an astonishing achievement and would surely make the entire world forget about the Suez fiasco and restore the image of a strong and victorious United Kingdom.

It seems that British politicians were conscious that the Falklands crisis was the perfect opportunity to restore British credibility as a great power, before, during and after the deployment of British forces. Before the Argentine invasion, Robert Armstrong, the Secretary of the Cabinet, wrote a minute to Margaret Thatcher in which he argued that the way Britain would settle the Falklands dispute would be decisive for British status and prestige: "a British readiness to surrender sovereignty over the Falklands Islands might have implications for the British position elsewhere in the world [....]. What would the international reactions be if the UK showed itself willing to negotiate with the Argentines over sovereignty of the Falklands Islands? Would this be regarded as another example of enlightened statesmanship, or simply another sign that GB is on the skids?" (Armstrong 1980). This note is very interesting because it is annotated by Thatcher and she underlined the last proposition, making clear that, to her, a retreat from the Falklands would be interpreted by the international community as a display of weakness. After the departure of the fleet, Members of Parliament also made the argument that the Falklands crisis would determine British future international standing. For example, Member of Parliament Winston Churchill (the grandson of the WWII Prime Minister) declared that failing to re-conquer the Falklands "would have repercussion [...]. Britain's standing and credibility in the world [...] will be judged by the resolution and determination with which we meet this challenge [...]" (HC Deb 7 April 1982, vol 21 cc 959-1052). And after the conflict, the argument that the victory in the Falklands reestablished Britain as a great power was repeatedly used by Thatcher in her speeches and in her autobiography: "our country has won a great victory and we are entitled to be proud [...]. Britain [still is] the nation that built an Empire and ruled a quarter of the world" (Thatcher 1982c). She continued in praising what made Britain special compared to other countries: "the British are competent, courageous and resolute" [...] The lesson of the Falklands is 
that Britain has not changed and that this nation still has those sterling qualities which shine through our history". 5

\section{Showing British commitment to great power status commitment:} defending international law principles by going to war against Argentina.

According to the definition of great power status, a great power has special duties and roles to perform. An expected duty from great powers is to manage the international system and thus to enforce the principles ruling it (Dafoe et al. 2014; Morris 2011). Two arguments evoking the duties of great powers were used by Britain to justify their decision to go to war: (1) defending the right of people to self-determination, and (2) protecting democracy from dictatorship.

(1) One can find reference to the right of people to self-determination in Thatcher's speeches before she became Prime Minister. In 1977, she was in the Shadow Cabinet and challenged the Labour government on its position regarding the Falklands during a Shadow Cabinet discussion the 23 February: "we should press the Foreign Secretary on his intentions and support the wish of the Islanders to remain British" (Shadow Cabinet 1977). "The wishes of the Falklands islanders are paramount" is one of the most frequently cited sentences by Thatcher. She used this expression in private as well as during public intervention. A good example of that is of her speech on 3 March 1982 in the House of Commons: "the people of the Falkland Islands, like the people of the United Kingdom, are an island race. They are few in number but they have the right to live in peace, to choose their own way of life and to determine their own allegiance. Their way of life is British; their allegiance is to the Crown. It is the wish of the British people and the duty of Her Majesty's Government to do everything that we can to uphold that right". She also reminds us of this position in her autobiography (Thatcher 1993: 175-176). Other British officials also referred to this position, such as the Falklands Governor Rex Hunt: "when he [the

5 See also her autobiography for another formulation of the same argument: "the significance of the Falklands was enormous, both for Britain's self-confidence and for our standing in the world. Since the Suez fiasco in 1956, the British Foreign policy had been one long retreat [...] we had come to be seen by both friends and enemies as a nation, which lacked the will and the capability to defend its interests in peace, let alone in war. Victory in the Falklands changed that" (Thatcher 1993: 173-175). The importance the Falklands crisis had is emphasized by the place Thatcher dedicated to it in her autobiography (40 pages in total). This suggests that there was a before and after watershed in the Falklands for Britain. 
governor] left the Falklands, he said that the people were in tears. They do not want to be Argentinean" (Thatcher 1982a).

(2) While the fleet was on its way to the Falklands, two resolutions were adopted by the UN Security Council: resolution 502 on 3 April and resolution 505 on 26 May. The first one consisted of demanding from Argentina a complete withdrawal from the Falklands and the second one calling Britain and Argentina to agree on a ceasefire before negotiations could start. In this context, The British government declared that the first use of the fleet dispatched is to be used as diplomatic support as Cecil Parkinson wrote to the Conservative constituency chairman: "it is a test for the whole nation. [...] any diplomatic solution must safeguard the principle that the wishes of the islanders shall remain paramount" [...] "the eyes of the world are now focused on the Falklands islands [...] to see whether brute force or the rule of law will triumph. Whether naked aggression occurs it must be overcome" (Parkinson 1982). . The fact that Argentina refused to follow resolution 502 and to evacuate the Falklands gave Britain the opportunity to take the role of the protector of international law and democracy against the aggression from authoritarianism (symbolized by Argentina). The rhetoric used by Thatcher reveals a clear description of the situation: "I'm standing up for the right of self-determination. I'm standing up for our territory. I'm standing up for our people. I'm standing up for international law. I'm standing up for all those territories - those small territories and peoples the world over - whom, if someone doesn't stand up and say to an invader 'enough, stop', would be at risk". 7 In a telegram to Ronald Reagan she wrote in May 1982, she saw the Falklands crisis as the continuation of the fight of democracy and freedom against dictatorship: "we shall fight fiercely for the rights of the Falklanders who have been so loyal to everything in which you and we believe" (Thatcher 1982b).

She went further in the assimilation of the Falklands crisis to the fight for freedom and democracy against dictatorship by making an analogy to Munich (1938). In Munich, Neville Chamberlain sacrificed a large portion of Czechoslovakia to Germany to "save" the peace, or so he thought (Breuning 2007: 56). Thatcher identified

6 The letter details Thatcher's motives to send the Royal Navy to the Falklands. Cecil Parkinson is at that time junior trade minister and a member of the war cabinet during the crisis.

7 About Thatcher clear-cutting understanding of the world see Stephen Benedict Dyson (2009: 40-41), Antony King (1985: 132) and Francis Pym (1984). 
herself as being in the same situation as Chamberlain, but this time Britain would not step down as the US Secretary of State Haig wrote after a meeting with Thatcher: "she rapped sharply on the tabletop and recalled that this was the table at which Neville Chamberlain sat in 1938 and spoke of Czechoslovakia as a faraway people about we know so little". Recalling that this omission had led to the eventual "death of 45 million people, she identified the Argentine challenge as a repeat performance" (Young 1989: 72) and compared Galtieri to Hitler: "a common or garden dictator should rule over the Queen's subjects and prevail by fraud and violence? Not while I was Prime Minister" (Thatcher 1993: 181).

\section{Conclusion}

This paper aimed to highlight the importance of an often disregarded argument to explain causes of war: considerations for status and prestige. Evidence supporting the argument that Britain re-conquered the Falklands to save its great power status can be found in the declassified documents. This article also aimed to make studies based on analysis of primary sources more popular, or at least to make such studies be more widely considered in the academic field. Declassified documents are unique sources for researches as they provide authentic insights on decision-making processes. In this article, I have followed a qualitative discourse analysis path. It would be very interesting to continue the analysis of the Falklands case study, but next time by using these documents for a quantitative study. A quantitative study would enable us measure and to make comparisons between lexicon fields referring to prestige considerations, domestic politics concerns and strategic concerns, to ascertain which one is the most prominent. 


\section{Bibliography}

Abdelal, R., Herrera, Y., Johnston, A. I., McDermott, R., 2009. Measuring identity. A guide for social scientist. Cambridge: Cambridge University Press.

Adkin, M., 1995. Goose Green. London: Orion Paperbacks.

Armstrong, R., 1980. Falkland Islands (OD(80) 46). [Minute] PM's office files, PREM 19/656 f82, Kew: The National Archives. Available at: http:// www.margaretthatcher.org/document/122466 (Accessed 17 September 2016).

Arquilla, J., Rasmussen, M., 2001. The origins of the South Atlantic war. Journal of Latin American Studies, 33(4): 739-775.

Aron, R., 1962. Paix et guerre entre les nation. Paris: Calmann-Lévy [2004].

Badie, B., 2013. L'impuissance de la puissance. Paris: CNRS Editions.

Barnett, M., Duvall, R., 2005. Power in International Politics. International Organization, 59(1): 39-75

Baron, J., 2013. Great power peace ad American primacy. The origine and future of a new international order. London: Palgrave Macmillan.

BBC News, 2012, Aircraft carriers crucial, Royal Navy chief warns. BBC News, 4 July [online]. Available at: http://www.bbc.com/news/uk18706505 (Accessed 17 March 2017).

Bluth, C., 1987. The British resort to force in the Falklands/Malvinas conflict 1982: international law and just war theory. Journal of Peace Reasearch, 24(1): 5-20.

Bukovansky, M., Clark, I., Eckersley, R., Price, R., Reus-Smit, C., Wheeler, N., 2012. Special responsibilities: global problems and America power. Cambridge: Cambridge University Press.

Bronk, J., 2014. Britain's "independent" V-bomber force and US nuclear weapons, 1957-1962. Journal of Strategic Studies, 37(6-7): 974-997.

Brown, C., 2004. Do great powers have great responsibilties? Great powers 
and moral agency. Global Society, 18(1): 5-19.

Calvert, P., 1983. Sovereignty and the Falklands crisis. International Affaires, 59(3): 405-413.

Calvert, P., 1982. The rights and the wrongs. New York: Saint Martin's Press. Carrington, P., 1979. Falkland Islands. [Minute], PM's office files, PREM 19/656 f118, Kew: The National Archives. Available at: http:// www.margaretthatcher.org/document/122458 (Accessed 16 September 2016).

Carrington, P., 1982. HMS Endurance. [Minute], FCO files, ALA 062/2, Kew: The National Archives. Available at: http://www.margaretthatcher. org/document/118422 (Accessed 17 September 2016).

Chassaigne, P., 2009. La Grande-Bretagne et le monde de 1815 à nos jours. Paris: Armand Colin.

Dafoe, A., Rensthen, J., and Huth, P., 2014. Reputation and status as motives for war. Annual Review of Political Science, 17: 371-393.

Dahl, R., 1957. The concept of Power. Systems Research Behavioral Science, 2(3): 201-215.

Darwin, J., 2009. The Empire project. The rise and fall of the British worldsystem, 1830-1970. Cambridge: Cambridge University Press.

de Waal-Andrews, W., Gregg, A., Lammers, J., 2015. When status is grabbed and when status is granted: getting ahead in dominance and prestige hierarchies. British Journal of Social Psychology, 54: 445-464.

Dillon, G., 1989. The Falklands: Politics and War. London: Macmillan.

Donghy, A., 2014. the British Government and the Falklands Islands, 19741979. London: Palgrave Macmillan.

Falkland Islands Government, 2013. Results of the referendum on the Political Status of the Falkland Islands. 12 March [Press release].. Available at http://www.falklands.gov.fk/results-of-the-referendum-on-thepolitical-status-of-the-falkland-islands/ (Accessed 6 July 2017).

Fearon, J., 1995. Rationalist explanation for war. International Organization, $49(3): 379-414$. 
Forsberg, T., Heller, R. and Wolf, R., 2014. Russia and the quest for status. Communist and Post-communist Studies, 47: 261-268.

Franck, T., 1983. Dulce et decorum est: the strategic role of legal principles in the Falklands war. The American Journal of International Relations, 77(11): 109-124.

Freedman, L., 1982. The war of the Falklands Islands. Foreign Affairs, 61 (1): 196-210.

Freedman, L., 1983. Britain and the Falklands war. Oxford: Basil Blackwell Inc.

Gamba, V., 1987. The Falklands/Malvinas War. A model for North-South crisis prevention. New York: HarperCollins Publishers.

Gochman, C. S. and Maoz, Z., 1984. Militarized interstate disputes, 18161976: procedures, patterns, and insights. The Journal of Conflict Resolution, 28(4): 585-616.

Haig, A., 1984. Caveat: realism, Reagan and foreign policy. New York: Scribner.

Hastings, M. and Jenkins, S., 1983. The battle for the Falklands. New York: W.W. Norton \& Company.

Howard, M., 1971. Studies in war and peace. New York: Viky.

Jackson, R., 2000. The global covenant. Human conduct in a world of states. Oxford: Oxford University Press.

Jervis, R., 1976. Perception and misperception in international politics. Princeton: Princeton University Press.

King, A., 1985. The British Prime Minister. London: MacMillan

Kinney, D., 1990. National interest/national honor: the diplomacy of the Falklands crisis, Westport: Greenwodd Press.

Lake, D., 2009. Hierarchy in international relations. Ithaca: Cornell University Press.

Lawrence, J. and Lawrence, R., 1988. When the fighting is over. Tumbledown. A personal story. London: Bloomsburry Publishing PLC.

Lebow, R. N., 1983. Miscalculation in the South Atlantic: the origines of the 
Falkland War. Journal of Strategic Studies, 6(1): 5-35.

Lebow, R. N., 2008. A cultural theory of international relations. Cambridge: Cambridge University Press.

Lebow, R. N., 2010. Why nations fight. Cambridge: Cambridge University Press.

Legro, J. W., 2005. Rethinking the world. Great powers strategies and international order. London: Cornell University Press.

Levy, J., 1983. War in the Modern Great power System 1495-1975. Lexington: The University Press of Kentucky.

Levy, J. and Vakili, L., 1992. Diversionary action by authoritarian regimes: Argentina in the Falklands/Malvinas case. In: Midlarsky, M. ed. The Internationalization of Communal Stripe. New York: Routledge. pp. 118-146.

Lindemann, T., 2010. Causes of War, the struggle for recognition. Colchester: ECPR.

Llyod, T. O., 1984. The British empire, 1558-1983. New York: Oxford University Press.

Love, T. and Davis, J., 2014. The effect of status on role-taking accurency. American Sociological Review, 79(5): 848-865.

Lukes, S., 1974. Power: a radical view, London: Macmillan Press.

Marsh, S., 2012. Anglo-American relations 1950-1951: three strikes for British prestige. Diplomacy and Statecraft, 23: 304-330.

Marshall, T., 1977. Class citizenship and social development: essays. Chicago: Chicago University Press.

Marx, R., 1993. Histoire de l'Angleterre. Paris: Editions Arthème Fayard.

McCourt, D., 2011. Role-playing and identity formation in international politics: Britain's reinvasion of the Falklands, 1982. Review of International Politics, 37: 1599-1621.

MacCourt, D., 2014. Britain and world power since 1945. Constructing a Nation's role in international politics. Ann Arbor: The University of Michigan Press. 
Mearsheimer, J., 2014. Tragedy of great power politics. New York: Norton and Company.

Méndez, N., 1993. Malvinas: ésta es la historia. Buenos Aires: Sudamericana. Menédez, M., 1983. Malvinas: testimonio de su gobernador. Buenos Aires: Sudamericana.

Middlebrook, M., 1989. The Fight for the Malvinas. London: Penguin.

Middlebrook, M., 1985. Operation Corporate: the story of the Falklands war, 1982. New York: The Viking Press.

Modelski, G. and Morgan, P., 1985. Understanding global war. Journal of Conflict resolution, 29(3): 391-417.

Morris, J., 2011. How great is Britain? Powers, responsibility and Britain's future global role. The British Journal of Politics and International Relations, 13: 326-347.

Onea, T., 2014. Between dominance and decline: status anxiety and great power rivalry. Review of International Studies, 40: 125-152.

O'Neill, B., 2001. Honor, symbols and war. Ann Arbor: the University of Michigan Press.

Parkinson, C., 1982. Letter to Conservative constituency chairmen, MPS and others (Falklands crisis). [Briefing note], THCR 2/11/1/34 f3, Cambridge: Churchill Archive Centre. Available at: http://www. margaretthatcher.org/document/123620 (Accessed 15 September 2016).

Parliamentary Archives, HC Deb 07 April 1982 vol 21 cc959-1052. Available at: http://hansard.millbanksystems.com/commons/1982/apr/07/ falkland-islands (Accessed 17 September 2016).

Paul, T. V., Welch Larson, D. and Wolhforth, W. C. eds., 2014. Status in world politics. Cambridge: Cambridge University Press.

Perl, R. and Larson, E., 1983. The Falklands dispute in international law and politics: a documentary sourcebook. Oceana Publication.

Piaggi, I., 1998. El combate de Goose Green. Buenos Aires: Planeta.

Pym, F., 1984. The Politics of consent. London: Hamisch Hamilton 
Ragim, C. C., 1987. The comparative method: moving beyong qualitative and quantitative strategies. Bekerley: University of California Press.

Robbins, K., 1994. The Eclipse of a great power. Modern Britain 1970-1992. London: Longman.

Rotberg, J. and Rubb, T. eds., 1984. The origins and preventions of major wars. Cambridge: Cambridge University Press.

Rothstein, R., 1968. Alliances and small powers. New York: Columbia University Press.

Sanders, D., 1990. Losing an Empire: finding a role. British foreign policy since 1945. London: Macmillan.

Saurette, P., 2006. You dissin me? Humiliations and post 9/11 global politics. Review of International Studies, 32(3): 495-522.

Scott, H. M., 2006. The birth of a Great power system 1740-1815. Harlow: Pearson Education Limited.

Sewell, B. and Ryan, M. eds., 2017. Foreign policy at the periphery. The shifting margins of US international relations since world war II. Lexington: The University Press of Kentucky.

Shadow Cabinet, 1977. Leader's consultative committee, Minutes to the 152nd committee, House of Commons, 23 February 1977. Available at: http://www.margaretthatcher.org/document/109713 (Accessed 14 September 2016).

Sharp, P., 2016. Thatcher's diplomacy. The revival of British foreign policy. London: Plagrave McMillan.

Schmitt, M. and Green, L., 1985. The Falklands crisis and the laws of war. International Law Studies, 70: 203-213.

Snyder, G. H. and Diesing, P., 1977. Conflict among nations. Bargaining, decision making and system structure in international crises. Princeton: Princeton University Press.

Sobek, D., 2007. Rallying around the podesta: testing diversionary theory accross time. Journal of Peace Research, 40(1): 29-45.

Thatcher, M., 1982a. Falkland Islands. Speech to the House of Commons, Hansard HC [21/633-38]. Available at: http://hansard. 
millbanksystems.com/commons/1982/apr/03/falkland-islands (Accessed 17 February 2017).

Thatcher, M., 1982b. MT expresses serious concerns about US/Peruvian peace proposals; proposes amendments. [Telegram] THCR 2/1/21 f24 (T97/82), Cambridge: Churchill Archive Centre. Available at: http://www.margaretthatcher.org/document/122864 [Accessed 15 September 2016].

Thatcher, M. 1982c. Speech to the conservative rally at Chelthenham. [online], 3 July 1982, Cheltenham Racecourse. Available at: https:// www.margaretthatcher.org/document/104989 (Accessed 15 September 2016).

Thatcher, M., 1993. The Downing street years. London: Hayer Collins publishers.

Thompson, J., 1992. No picnic. London: Cassel.

Volgy, T. J., Corbetta, R., Grant, K. A. and Baird, R. G., 2011 . Major powers and the quest for status in international politics. Global and regional perspectives. New York: Palgrave McMillan.

Waltz, K., 1968. International structure, national force, and the balance of world power. In: Farrel, J. and Smith, A., Theory and relaity in international relations. New York: Columbia University Press. pp. 31-47.

Waltz, K., 1979. Theory of International politics. London: Addison-Wesley.

Weinberger, C., 1990. Fighting for peace: seven years in the Pentagon. New York: Grand Central Publishing.

Welch, D., 1997. Remember the Falklands? Missed lessons of a misunderstood conflict. International Journal, summer 1997: 483508.

Welch, D., 2005. Painful Choices. A theory of foreign policy change. Princeton: Princeton University Press.

Welch Larson, D. and Schevchenko, A., 2010. Status, Identity, And Rising Powers. Paper presented at the CIPSS/CEPSI Workshop on International Security and Political Economy, McGill University.

Williams, P., 1983. Miscalculation, crisis management and the Falklands 
conflict. The World Today, 39(4): 144-149.

Windsor, P., 1983. Diplomatic dimensions of the Falklands Crisis. Millennium: Journal of International Studies, 12(1): 88-96.

Woodward, J., 1992. One hundred day: the memoirs of the battle group commanders. Annapolis: Naval Institute Press.

Young, H., 1989. A biography of Margaret Thatcher. London: Macmillan

Matthieu Grandpierron (matthieu.grandpierron@polytechnique.edu) is a PhD candidate at Ecole Polytechnique, University ParisSaclay and at the University of Ottawa. His PhD dissertation is about how status recognition and conceptions of power of decision-makers have shaped great powers' interventions in their periphery. His research interests are: great powers' wars, status recognition, China's foreign policy, and nuclear deterrence. Beside his researches, Matthieu Grandpierron lectures about international relations and comparative political institutions at Paris VIII Vincennes Saint-Denis, and at Institut Catholique d'Etudes Supérieures (ICES). 